\title{
Immune Complexes in Sera and Synovial Fluids of Patients with Rheumatoid Arthritis
}

\author{
RADIOIMMUNOASSAY WITH MONOCLONAL \\ RHEUMATOID FACTOR
}

\author{
Harvinder S. Luthra, Frederic C. McDuffie, Gene G. Hunder, and \\ Eduardo A. Samayoa \\ From the Departments of Medicine, Immunology, and Microbiology, Mayo \\ Foundation, Rochester, Minnesota 55901
}

\begin{abstract}
A B S T R A C T Evidence for the presence of immune complexes in blood, synovial fluid, and tissues of patients with rheumatoid arthritis (RA) includes low complement levels in blood and effusions, deposition of immunoreactants in tissues and vessel walls, and precipitate formation after addition of monoclonal rheumatoid factor (mRF) to serum or synovial fluid. To quantitate immune complex-like material in RA patients, we developed a radioimmunoassay based on inhibition by test samples of the interaction of $\left[{ }^{130} \mathrm{I}\right]$ aggregated IgG (agg IgG) and mRF coupled to cellulose. This method could measure immune complexes of human antibody with hemocyanin prepared in vitro. The assay was not influenced by presence of polyclonal RF in test samples, nor by freezing and thawing. Normal levels of immune complex-like material in serum were less than $25 \mu \mathrm{g}$ agg IgG eq/ml. 12 of $51 \mathrm{RA}$ sera examined $(26 \%)$ contained more than $25 \mu \mathrm{g} / \mathrm{ml}$. The presence of this material in RA sera was found to correlate with severity of disease, as measured by anatomical stage and functional class. There was an inverse correlation of the material with serum C4 level. Rheumatoid synovial fluids generally contained higher levels than serum, and five of 23 contained very much higher levels. The frequency of elevated levels of immune complex-like material in sera of patients with systemic lupus erythematosus (2 of 29) and with miscellaneous vasculitides (2 of 21) was much lower than in RA, suggesting that $\mathrm{mRF}$ ex-
\end{abstract}

Results of this work were presented in part at the 6th Pan-American Congress on Rheumatic Diseases, Toronto, Ontario, 18 June 1974.

Received for publication 31 December 1974 and in revised form 10 April 1975. hibits a specificity for only certain kinds of immune complexes. The reason for this apparent specificity may explain such distinctive features of RA as the high frequency of polyclonal $R F$, the lack of immune complex nephritis, and the generally normal levels of serum complement.

\section{INTRODUCTION}

Sera and synovial fluids from patients with rheumatoid arthritis (RA) ${ }^{1}$ have been shown to possess high molecular weight material that contains immunoglobulins and may represent immune complexes (1-7). Winchester, Agnello, and Kunkel have shown a close correlation between the presence of this material in synovial fluid and low levels of complement (4). These high molecular weight complexes may well play a significant role in the chronic inflammatory process that characterizes this disease. However, the precise role of these presumed complexes in RA is still not known. One significant limitation to learning more about the nature of this material and its relationship to the clinical features of RA has been the lack of a sensitive, easily performed, and reproducible quantitative method for measuring it. Winchester et al. (4) measured the amount of material in synovial fluid precipitable with monoclonal rheumatoid factor (mRF) by the quantitative precipitin test but this method is cumbersome and requires relatively large amounts of the reagent, $\mathrm{mRF}$.

\footnotetext{
${ }^{1}$ Abbreviations used in this paper: agg IgG, heat-aggregated IgG; $\mathrm{m}$, monoclonal; RA, rheumatoid arthritis; RBAF, rheumatoid biologically active factor; RF, rheumatoid factor; SLE, systemic lupus erythematosus.
} 
These same authors (5) have also reported the use of monoclonal rheumatoid factors in double immunodiffusion for demonstrating these immune complexes in rheumatoid sera and synovial fluids. Although useful in detecting this material, the technique is not quantitative, and weak precipitin reactions are hard to read with confidence. As a result, we have developed a solid-phase radioimmunoassay $(8)$, in which an $\mathrm{mRF}$ conjugated to microcrystalline cellulose and heat-aggregated $\mathrm{IgG}$ (agg IgG) served as reagent. With this technique, we were able to demonstrate the presence of immune complex-like material in the sera of about one-fourth of patients with RA and to show that its presence is related to indices of disease severity.

\section{METHODS}

$m R F$ : isolation and conjugation to microcrystalline cellu lose. Monoclonal IgM, kappa, rheumatoid factor (mRF) was separated from $5 \mathrm{ml}$ of serum of a patient with severe cutaneous vasculitis and an uncharacterized lymphoproliferative disorder. It was dialyzed against $0.1 \mathrm{M}$ glycine $\mathrm{HCl}$, $\mathrm{pH} 3.0$, buffer for $12 \mathrm{~h}$ at $4^{\circ} \mathrm{C}$ and then applied to a Sephadex G-200 column in the same buffer. The exclusion volume protein peak was conjugated to Avicel microcrystalline cellulose (Brinkmann Instruments, Inc., Westbury, N. Y.) by a method based on that of Axen, Porath, and Ernback (9). We used $\mathrm{mRF}$, microcrystalline cellulose, and cyanogen bromide in a ratio of $1: 10: 80$. After $48 \mathrm{~h}$, the conjugate was washed and the amount of bound protein calculated by subtraction of recovered unbound protein. About $70 \%$ of the added protein was usually bound to cellulose.

Preparation of $\left[{ }^{125} I\right]$ aggregated IgG. Aggregated IgG was prepared by heating human Cohn fraction II (Miles Laboratories, Inc., Elkhart, Ind.) at $63^{\circ} \mathrm{C}$ (temperature inside tube) for $10 \mathrm{~min}$ and subsequently precipitating at $0.62 \mathrm{M}$ sodium sulfate at $25^{\circ} \mathrm{C}(10)$. The aggregates were dissolved in neutral buffer, applied to a 5-40\% sucrose density gradient, and centrifuged at $283,000 \mathrm{~g}$ (bottom of the tubes) for $6 \mathrm{~h}$ in an International B-60 ultracentrifuge in a SW 283 rotor $(40,000 \mathrm{rpm})$ (Damon/LEC, Needham Heights, Mass.). Tubes containing aggregates of approximately 25S were pooled and used in subsequent studies. Aggregated IgG was radiolabeled with ${ }^{105} \mathrm{I}$ by the method of Hunter and Greenwood (11). We mixed $2.0 \mathrm{mg}$ of agg IgG in $5.0 \mathrm{ml}$ of $0.1 \mathrm{M}$ Tris, $0.2 \mathrm{M} \mathrm{NaCl}, \mathrm{pH} 8.0$, buffer with $0.56 \mathrm{mCi}$ of carrier-free ${ }^{185} \mathrm{I}$ with constant stirring. Then $0.5 \mathrm{mg}$ of chloramine- $\mathrm{T}$ in $0.1 \mathrm{ml}$ of $\mathrm{pH} 7.0$ phosphatebuffered saline was added, and exactly $1 \mathrm{~min}$ later 0.25 $\mathrm{mg}$ of sodium metabisulphite in $0.1 \mathrm{ml}$ of phosphate-buffered saline. The mixture was passed through a $1 \times 25-\mathrm{cm}$ Sephadex G-25 column, and the tubes containing the first radioactive peak were pooled. The specific activity of most preparations was about $0.2 \mathrm{mCi} / \mathrm{mg}$.

Solid phase radioimmunoassay. Optimal amounts of conjugated $\mathrm{mRF}$ and agg IgG were determined by preliminary trials. Reagents were dissolved or suspended in $0.075 \mathrm{M}$ phosphate, $0.075 \mathrm{M} \mathrm{NaCl}, \mathrm{pH} 7.5$, buffer containing $1 \%$ bovine serum albumin. Capped polystyrene tubes, $11 \times 63$ mm (Luckman Limited, Burgess Hill, Sussex, England) were used, as they gave the least nonspecific binding of several batches of tubes tested. Into each tube were added in order $0.5 \mathrm{ml}$ of test solution, $0.5 \mathrm{ml}$ of [ $\left.{ }^{125} \mathrm{I}\right] \mathrm{agg}$ IgG containing $0.27 \mu \mathrm{g}$ of protein, and $0.5 \mathrm{ml}$ of conjugated $\mathrm{mRF}$ containing $2.0 \mu \mathrm{g}$ of protein bound to $27 \mu \mathrm{g}$ of cellulose. The tubes were incubated with continuous rotation for $1 \mathrm{~h}$ at $37^{\circ} \mathrm{C}$ and $12 \mathrm{~h}$ at $4^{\circ} \mathrm{C}$. After centrifugation and washing three times with $1.0-\mathrm{ml}$ portions of buffer, the conjugate was resuspended and the radioactivity counted in a NuclearChicago automatic scintillation counter (Nuclear-Chicago Corp., Des Plaines, Ill.). Before assay, human sera and effusions were analyzed for 7S IgG content by the radial immunodiffusion technique (12) and were diluted to a final 7S IgG concentration of $60 \mu \mathrm{g} / \mathrm{ml}$. Portions of $0.5 \mathrm{ml}$ of this solution were used for assay. This latter procedure was carried out to compensate for any interference by $7 \mathrm{~S}$ IgG in the sample with the assay (see Results).

A standard curve was prepared for each assay by adding different amounts of agg IgG $(1-150 \mu \mathrm{g})$ to a normal human serum of known 7S IgG content and then diluting these samples for assay. The amount of reacting material in test sera and fluids was calculated by reference to the plot of counts per minute vs. agg IgG content. Results were expressed as micrograms of agg IgG equivalent per milliliter in the original specimen. These standard curves were submitted to regression analysis, and if the coefficient of correlation was less than 0.98 , the results of the assay were discarded.

Density gradient ultracentrifugation. Density gradient ultracentrifugation was carried out on a $5-30 \%$ sucrose density gradient in $0.1 \mathrm{M}$ Tris, $0.2 \mathrm{M} \mathrm{NaCl}, \mathrm{pH} 8.0$, buffer, on which we layered $0.5 \mathrm{ml}$ of sample, before centrifugation at $283,000 \mathrm{~g}$ (at the bottom of the tube) for $12 \mathrm{~h}$ at $4^{\circ} \mathrm{C}$ in an International B-60 ultracentrifuge in a SW 283 rotor. The positions of IgG and IgM in normal human serum were determined by radial immunodiffusion and used as 7S and 195 markers.

Collection of samples. All sera were allowed to clot at room temperature and were stored at $4^{\circ} \mathrm{C}$ after addition of $1 \%$ sodium azide as preservative. All synovial fluids were treated with hyaluronidase, $0.2 \mu \mathrm{g} / \mathrm{ml}$ of fluid, and stored at $4^{\circ} \mathrm{C}$ after addition of $1 \%$ azide. 102 normal human sera were collected from healthy adults donating blood to the blood bank. Plasma was collected from hospitalized patients undergoing diagnostic tests. Specimens of rheumatic disease patients were identified by review of clinical records. Sera and synovial fluids were also obtained from patients with RA, systemic lupus erythematosus (SLE), and miscellaneous vasculitides whose sera and synovial fluids had been obtained previously for various tests and had been stored at $-70^{\circ} \mathrm{C}$

Analysis of clinical data. Clinical data were abstracted from each patient's record. The anatomical stage of disease of patients with RA was estimated by reviewing the available X-rays of involved joints (13). The modified 1958 criteria of Ropes, Bennett, Cobb, Jacox, and Jessar (14) were used to classify these patients as having probable, definite, or classical RA.

C4 determination. C4 levels were determined by radial immunodiffusion in plates containing agar mixed with monospecific antiserum to $\mathrm{C} 4$ made by us.

\section{RESULTS}

Isolation of $m R F$ and conjugation. The results of chromatography of the serum containing $\mathrm{mRF}$ on Sephadex G-200 are shown in Fig. 1. The mRF eluted in the first peak. It contained a small amount of bound IgG, which, however, did not interfere with the subsequent assay. 


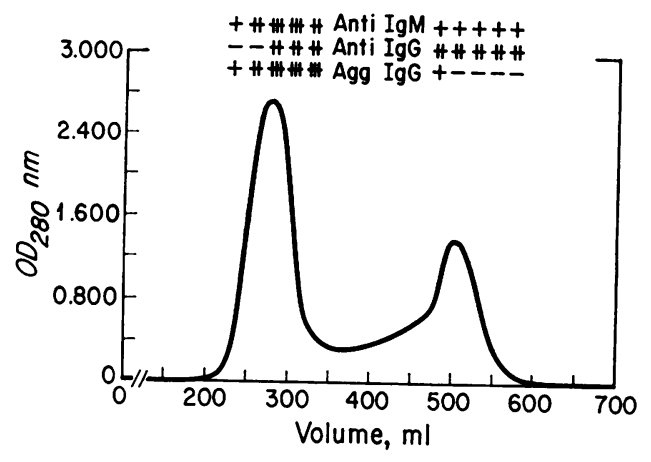

FIGURE 1 Chromatography of serum containing mRF on Sephadex G-200 at pH 3.0. Symbols at top indicate results of testing effluent fractions against appropriate antisera or against agg IgG in double immunodiffusion.

Effect of $7 S I g G$ on the assay for immune complexes. Fig. 2 shows the results obtained in an experiment in which samples of agg $\operatorname{IgG}$ of known concentration in buffer were tested in the assay. A characteristic inhibition curve was obtained, maximum sensitivity being obtained in the range of $2-7 \mu \mathrm{g} / \mathrm{ml}$. Because of known reactivity of $\mathrm{RF}$ with $7 \mathrm{~S} \operatorname{IgG}(15,16)$ and the presence of large amounts of 7S IgG in serum, it was essential to examine the effect of $7 \mathrm{~S} \mathrm{IgG} \mathrm{on} \mathrm{the} \mathrm{immunoassay} \mathrm{for}$ aggregates. Thus the assay was simultaneously carried out on a sample of 7S IgG cleared of any contaminating aggregates by ultracentrifugation at $40,000 \mathrm{rpm}$ for 3 h. This 7S IgG did produce some inhibition of binding of $\left[{ }^{125} \mathrm{I}\right] \mathrm{agg}$ IgG to $\mathrm{mRF}$; but as shown in Fig. 2, $50 \mu \mathrm{g}$ of $7 \mathrm{~S} \mathrm{IgG} \mathrm{was} \mathrm{required} \mathrm{to} \mathrm{produce} \mathrm{the} \mathrm{same} \mathrm{inhibition}$ of binding as less than $1 \mu \mathrm{g}$ of agg $\mathrm{IgG}$. As a result, however, of this demonstrated binding of $7 \mathrm{~S} \mathrm{IgG} \mathrm{to}$ the conjugated $\mathrm{mRF}$, a correction for this effect on assays of biological materials was built into the assay by

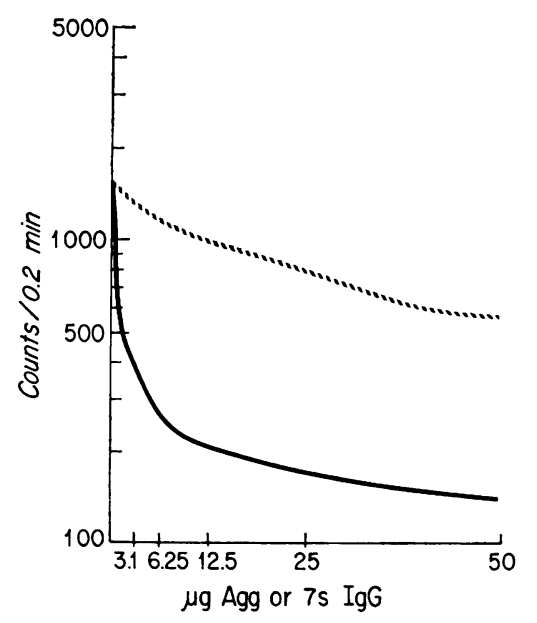

FIGURE 2 Inhibition of binding of [ $\left.{ }^{200} \mathrm{I}\right]$ agg $\mathrm{IgG}$ by solid phase $\mathrm{mRF}$ in the presence of $7 \mathrm{~S}$ IgG (-.) or aggregated IgG (—).

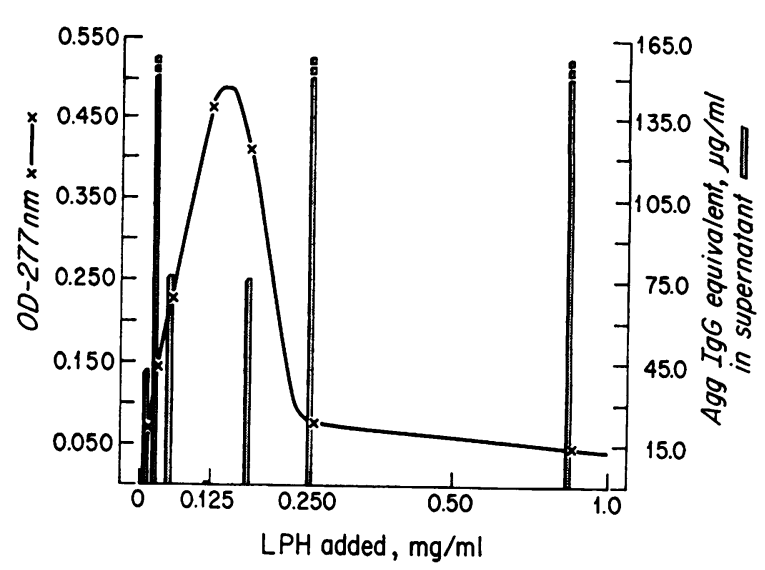

FIGURE 3 Hemocyanin-human antihemocyanin precipitin curve. To $1.0-\mathrm{ml}$ samples of human antihemocyanin, portions of Limulus polyphemus hemocyanin (LPH) were added. The washed immune precipitates were analyzed for protein by spectrophotometry at $277 \mathrm{~nm}$, and the supernates assayed for aggregated IgG equivalent by solid phase radioimmunoassay. - $\times-\mathrm{OD}_{277 n m}$ of immune precipitate. Bars represents amount of aggregated IgG equivalent measured in each supernate by radioimmunoassay.

diluting all samples to a constant $7 \mathrm{~S}$ IgG content of $60 \mu \mathrm{g} / \mathrm{ml}$ and introducing this same amount of $7 \mathrm{~S} \mathrm{IgG}$ into all aggregate samples used in preparation of each standard curve.

Hemocyanin-antihemocyanin complexes. Though the results in Fig. 2 demonstrated that artificially aggregated IgG could be measured in this assay, it was necessary to show that the method could actually quantitate antigenantibody complexes. Thus supernates from a Limulus polyphemus hemocyanin (LPH)-human antihemocyanin precipitin curve were examined for immune complexes (Fig. 3). At the equivalence point, $0.125 \mathrm{mg} / \mathrm{ml}$ of hemocyanin, as determined by examining the supernates in double immunodiffusion (17), no reactivity with $\mathrm{mRF}$ was detected by radioimmunoassay. However, immune complexes were measurable in the supernates both in region of antibody excess (tubes containing less than 0.125 $\mathrm{mg} \mathrm{LPH}$ ) and in region of antigen excess (tubes containing more than $0.125 \mathrm{mg}$ LPH).

Effect of polyclonal $R F$ on the immunoassay. Since rheumatoid sera and fluids generally contain large amounts of polyclonal RF, we examined the effect of polyclonal RF on the assay. Such RF might bind to the $\left[{ }^{150} \mathrm{I}\right] \mathrm{agg} \mathrm{IgG}$ in the tubes and inhibit binding to the $\mathrm{mRF}$ conjugate. Polyclonal RF was isolated from the serum of a patient with RA by the same technique used for $m R F$ described above. Different amounts of this RF were added to normal human serum to yield final $R F$ titers of $1: 250-1: 64,000$. As shown in Fig. 4, there was no effect on binding of $\left[{ }^{15} \mathrm{I}\right] \mathrm{agg}$ IgG to conjugated mRF up to a titer of $1: 16,000$. Even in serum with an 
RF titer of $1: 64,000$, there was only a $25 \%$ reduction in binding. We also examined the effect of polyclonal $\mathrm{RF}$ on the determination of complexes in a serum known to contain such material. The data in Table I demonstrate the negligible effect of polyclonal RF on the results obtained with a serum containing hemocyaninantihemocyanin complexes.

Reproducibility of immunoassay and effects of heating and freezing sera. 14 sera containing 1 to more than $150 \mu \mathrm{g}$ agg $\mathrm{IgG}$ eq $/ \mathrm{ml}$ were assayed several times. Of these, two were assayed seven times each and the variation in the results was less than $5 \% .10$ sera were assayed twice with less than $5 \%$ difference between the individual samples in each pair. Two additional sera gave results which varied significantly. One, assayed twice, showed results of 1 and $25 \mu \mathrm{g} / \mathrm{ml}$ of agg IgG equivalent and the other yielded results of 50,68 , and 11 $\mu \mathrm{g}$ of agg IgG eq/ml on different occasions.

Heating sera at $56^{\circ} \mathrm{C}$ for $60 \mathrm{~min}$ to inactivate complement resulted in the appearance of inhibitory activity, probably resulting from the formation of aggregates. Therefore, all sera and fluids were used without heating.

Freezing at $-20^{\circ} \mathrm{C}$ and thawing sera seven times did not result in any change in the amount of reacting material, as compared with that of samples stored at $4^{\circ} \mathrm{C}$. Thus use of sera and synovial fluids stored at $-70^{\circ} \mathrm{C}$ and thawed two to three times did not affect the results.

Density gradient ultracentrifugation. In order to estimate the size of reacting material, rheumatoid sera found to contain material reacting in the assay were applied to $5-30 \%$ sucrose density gradients and the fractions assayed by immunoassay. Fig. $5 a$ and $b$ dem-

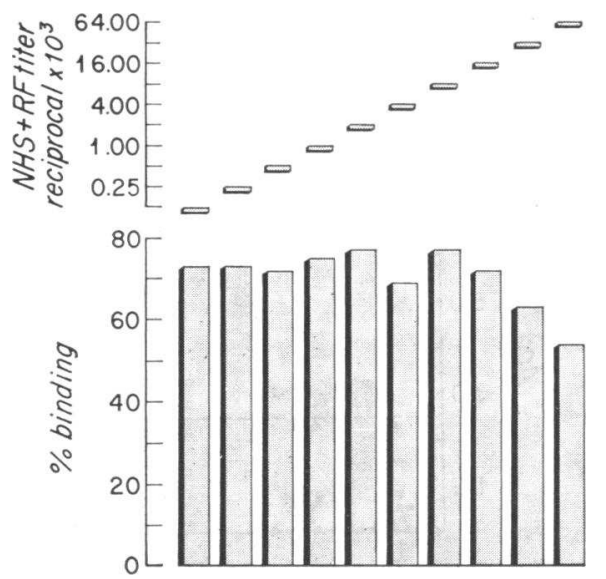

FIGURE 4 Effect of adding isolated polyclonal RF on the inhibition of binding of $\left.{ }^{125} \mathrm{I}\right]$ agg IgG to conjugated $\mathrm{mRF}$. Thick vertical bars represent amount of binding of $\left[{ }^{125} \mathrm{I}\right]$ agg IgG in presence of normal serum to which polyclonal RF has been added to produce the final RF titers shown by the thin horizontal bars in the upper part of the figure. NHS, normal human serum.
TABLE I

Effect of Addition of Polyclonal $R F$ on Measurement of

Hemocyanin-Antihemocyanin Immune Complexes

\begin{tabular}{ccc}
\hline & \multicolumn{2}{c}{ Agg IgG eq. } \\
\cline { 2 - 3 } Rheumatoid factor & $\begin{array}{c}\text { No hemocyanin } \\
\text { added }\end{array}$ & $\begin{array}{c}\text { Hemocyanin } \\
(0.25 \mathrm{mg} / \mathrm{ml})\end{array}$ \\
\hline final titer-1 & \multicolumn{3}{c}{$\mu \mathrm{g} / \mathrm{ml}$} \\
None & 11 & 83 \\
320 & 14 & 76 \\
640 & 16 & 83 \\
1,280 & 12 & 92
\end{tabular}

Purified polyclonal IgM RF was added to human antihemocyanin to produce RF titers shown above. $0.25 \mathrm{mg}$ hemocyanin was added to produce moderate antigen excess as determined from quantitative precipitin curve (see Fig. 3).

onstrate that immune complex-like material of both intermediate (approximately 11S) and heavy size (19S and larger) was measured by the assay in rheumatoid sera.

Assay of human sera. The results of assay of several groups of human sera are shown in Fig. 6. Of 102 normal human sera only $2(2 \%)$ contained more than 25 $\mu \mathrm{g}$ agg IgG eq/ml. Thus we chose $25 \mu \mathrm{g}$ of agg IgG $\mathrm{eq} / \mathrm{ml}$ as the upper limit of normal. Among the hospitalized nonrheumatic disease patients, sera of 6 of 67 (9\%) contained more than $25 \mu \mathrm{g}$ agg $\mathrm{IgG} \mathrm{eq} / \mathrm{ml}$. These six patients had the following diseases; two, subacute bacterial endocarditis with glomerulonephritis; one, recurrent pulmonary emboli with an unclassified myeloproliferative disorder; one, regional enteritis with Pseudomonas pneumonia; one, inactive rheumatic heart disease; and one, clinically normal. This last patient had an RF titer 1:20,480, negative lupus-erythematosis cell test, and no antinuclear antibody.

Among the sera from patients with rheumatoid arthritis, 12 of $46(26 \%)$ contained more than $25 \mu \mathrm{g}$ agg IgG eq/ml, 11 of these patients was seropositive, and all twelve had definite or classical RA. For statistical analyses, the rheumatoid patients were divided into two groups: one, patients whose sera contained $25 \mu \mathrm{g}$ agg $\mathrm{IgG} \mathrm{eq} / \mathrm{ml}$ or less, and two, patients whose sera contained more than $25 \mu \mathrm{g}$ agg $\mathrm{IgG}$ eq $/ \mathrm{ml}$. The duration of disease for the two groups was found to be longer in the patients with immune complexes at $P=0.05$ level, by a two-sided rank sum test. An association between severity of disease as measured by functional class (Fig. 7) and anatomical stage (Fig. 8) on the one hand and presence of immune complexes on the other was demonstrable by the $\chi$ square test $(P=$ 0.025 and 0.05 , respectively). No correlation was found with the erythrocyte sedimentation rate or RF titer ( IgG or IgM). However, comparison of the $\mathrm{C} 4$ levels between 

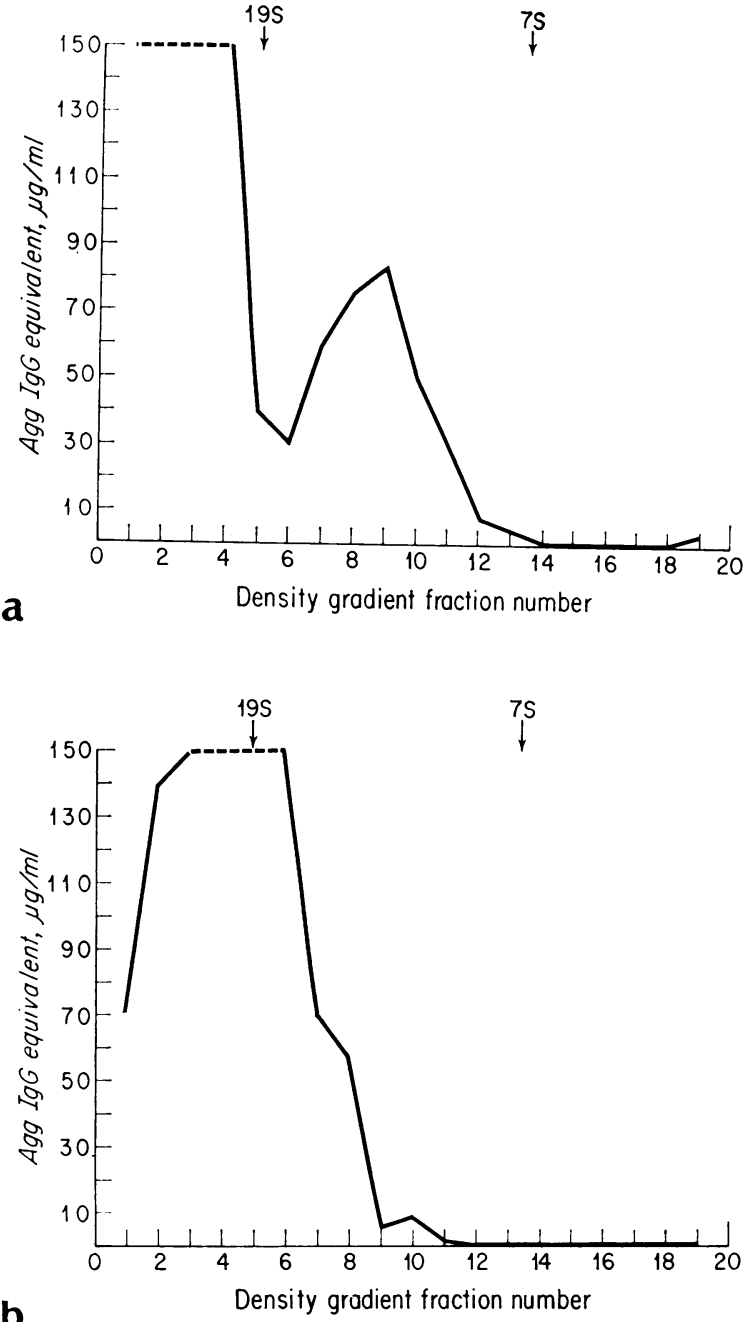

b

Figure $5 a$ and $b$ Radioimmunoassay results of sucrose density gradient fractions on two sera from patients with rheumatoid arthritis. Tube 1 represents bottom tube. $\uparrow \uparrow$ indicate position of $19 \mathrm{~S}$ IgM and 7S IgG.

the two groups revealed a significant difference ( $P=$ 0.001 by a two-sided rank sum test). Using Spearman's rank correlation coefficient, we found agg IgG and C4 to be negatively correlated $\left(r_{\mathrm{s}}=-0.449, P=0.003\right)$. Clinical data of the 12 rheumatoid patients with elevated levels of agg $\mathrm{IgG}$ are shown in Table II.

Only 2 of $29(7 \%)$ SLE sera and 2 of 21 (10\%) miscellaneous vasculitides sera showed significant reactivity with $\mathrm{mRF}$ conjugate (Fig. 6). One positive patient with SLE had minimal focal membranous changes on renal biopsy and a low serum complement level, while the other had clinically inactive disease with normal total hemolytic complement and no renal involvement. Of 24 SLE patients with less than $25 \mu \mathrm{g}$ agg $\mathrm{IgG}$ eq $/ \mathrm{ml}$ on whom serum complement was determined, 7 had low levels. Of the patients in the miscellaneous vasculitides

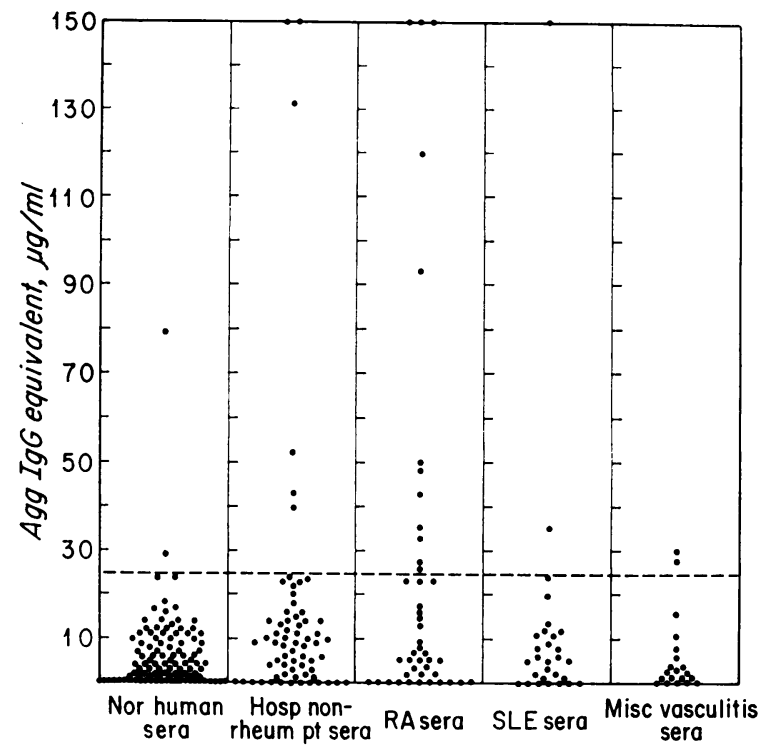

FIgure 6 Solid phase radioimmunoassay results of sera from normal individuals and patients with several diseases.

group who had elevated levels of agg $\operatorname{IgG}$, one had a systemic arteritis and the other Löffler's syndrome with pulmonary vasculitis.

Synovial fluids. On assay of 40 synovial fluids, we found that 5 of $23(22 \%)$ from patients with RA, none



Functional class (ARA criteria)

FIGURE 7 Correlation between the amount of aggregated IgG equivalent in sera of patients having $R A$ and the functional class of their disease. For $\chi$ square test, classes III and IV were combined. The analysis showed an association between functional class and aggregated IgG equivalent level $(P=0.025)$. 
TABLE II

Clinical Features of Rheumatoid Patients with High Levels of Immune Complex-Like Material in Serum

\begin{tabular}{|c|c|c|c|c|c|c|c|c|c|}
\hline Patient & Sex & Age & $\begin{array}{c}\text { Duration } \\
\text { of RA }\end{array}$ & $\begin{array}{l}\text { ARA class } \\
\text { and stage }\end{array}$ & RF titer* & LE cell & $\begin{array}{l}\text { ANA } \\
\text { titer }\end{array}$ & Agg IgG & $\begin{array}{l}\text { Extra-articular } \\
\text { manifestations }\end{array}$ \\
\hline no & & $y r$ & $y r$ & & & & & $\mu g$ eq $/ m l$ & \\
\hline L168 & $\mathrm{F}$ & 57 & 12 & III ; II & $1: 128,000$ & Hem. bodies & $1: 256$ & $>150$ & $\begin{array}{l}\text { Sjögren's syndrome } \\
\text { and leg ulcers }\end{array}$ \\
\hline L169 & $\mathrm{F}$ & 68 & 17 & II ; III & $1: 128,000$ & Neg. & $\mathrm{ND}$ & $>150$ & None \\
\hline L189 & $\mathrm{F}$ & 78 & 37 & III ; III & $1: 256,000$ & ND & $\begin{array}{l}1: 128 \\
\text { mixed }\end{array}$ & $>150$ & Sjögren's syndrome \\
\hline $\mathrm{L} 174$ & $\mathrm{M}$ & 64 & 20 & II ; III & $1: 64$ & Neg. & ND & 120 & Sjögren's syndrome \\
\hline $\mathrm{L} 171$ & $\mathrm{~F}$ & 42 & 12 & II ; III & $1: 4,000$ & Pos. & $\begin{array}{l}1: 256 \\
\text { mixed }\end{array}$ & 93 & $\begin{array}{l}\text { Felty's syndrome } \\
\text { and basilar } \\
\text { lung fibrosis }\end{array}$ \\
\hline L173 & $\mathrm{F}$ & 58 & 11 & II ; II & $1: 4,000$ & Pos. & ND & 50 & Sjögren's syndrome \\
\hline $\mathrm{L} 172$ & $\mathrm{~F}$ & 54 & 30 & III & $1: 4,000$ & ND & $\begin{array}{l}1: 32 \\
\text { mixed }\end{array}$ & 48 & $\begin{array}{l}\text { Leg ulcers and } \\
\text { neuropathy }\end{array}$ \\
\hline L311 & $\mathbf{M}$ & 50 & 2 & II ; II & $1: 8,000$ & ND & ND & 43 & None \\
\hline L167 & $\mathbf{M}$ & 59 & 13 & III ; III & $1: 400$ & Neg. & Neg. & 35 & Basilar lung fibrosis \\
\hline L82 & $\mathrm{F}$ & 71 & 10 & II ; II & Neg. & Rosettes & Neg. & 33 & Leg ulcers \\
\hline $\mathrm{L} 262$ & $\mathrm{~F}$ & 45 & 20 & II ; III & $1: 512$ & Neg. & ND & 27 & Felty's syndrome \\
\hline L339 & $\mathrm{M}$ & 30 & $1 \frac{1}{2}$ & II ; III & $1: 8,000$ & Rosettes & $\begin{array}{l}1: 32 \\
\text { mixed }\end{array}$ & 26 & None \\
\hline
\end{tabular}

* Rheumatoid factor by sensitized human cell test (Ripley).

$\ddagger$ Antinuclear antibody by immunofluorescent test.

ND, Not done.

of 6 patients with SLE, and none of 11 synovial fluids from patients with miscellaneous diseases showed more than $25 \mu \mathrm{g}$ agg $\mathrm{IgG} \mathrm{eq} / \mathrm{ml}$. The miscellaneous group consisted of five degenerative joint diseases, two effu-

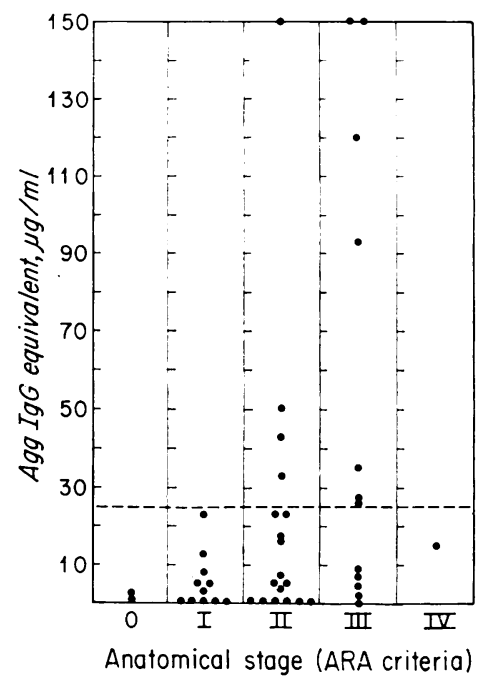

FIGURE 8 Correlation between the amount of aggregated IgG equivalent in sera of patients having $R A$ and the anatomical stage of their disease. For $\chi$ square test stages 0 and I and stages III and IV were combined. The $x$ square test indicated an association between the anatomical stage and the level of aggregated IgG equivalent $(P=$ $0.05)$.

sions of undetermined etiology, and one each of pseudogout, psoriasis, ankylosing spondylitis, and intermittent hydroarthrosis (Fig. 9).

We were not able to establish a statistically significant relationship between $\mathrm{C} 4$ and agg IgG in rheumatoid



FIGURE 9 Amount of aggregated IgG equivalent in paired sera and synovial fluids from patients with RA and from patients with other diseases. 
synovial fluids by Spearman's rank correlation coefficient, as had been possible for serum. A two-sided rank sum test did reveal that mean complement levels were significantly lower in fluids containing immune complexes $(P=0.05)$.

Fig. 9 shows results of comparing paired sera and synovial fluids in rheumatoid and miscellaneous disease patients. Four rheumatoid synovial fluids contained significant amounts of agg IgG activity and each contained more than was present in the corresponding serum. Thus it appears unlikely that the synovial fluid material represented only transport of immune complex material from the serum.

\section{DISCUSSION}

In the last few years both direct and indirect evidence has accumulated for the presence of immune complexes in patients with RA. Fish, Michael, Gewurz, and Good (18) and Rodman, Williams, Bilka, and Müller-Eberhard (19) used the immunofluorescent technique to demonstrate the presence of immunoglobulins ( $\operatorname{IgG}$ and IgM) and complement in the synovial membrane of patients with RA and suggested that the presence of these immunoreactants represented deposits of immune complexes of unknown origin. Conn, McDuffie, and Dyck (20) found similar deposits in the walls of nutrient vessels of sural nerves of patients with rheumatoid neuropathy. Previously Pekin and Zvaifler $(21,22)$ and Hedberg (23) had reported disproportionately low levels of hemolytic complement in the synovial fluids as compared to the sera in patients with RA. Subsequently, Franco and Schur (24) and Hunder and McDuffie (2) reported low serum levels of complement in certain rheumatoid patients: observations consistent with complement consumption by immune aggregates.

Direct evidence of the presence of immune complexlike material in RA had been provided as early as 1957 by Franklin, Holman, Müller-Eberhard, and Kunkel (1), who demonstrated by analytical ultracentrifugation the presence of a high molecular weight material (22S) in the serum of RA patients, a material which could be reversibly dissociated into $7 \mathrm{~S}$ and $19 \mathrm{~S}$ components by exposure to $\mathrm{pH} 3.0$ or to $4-6 \mathrm{M}$ urea. Chodirker and Tomasi in 1963 (25) identified in certain rheumatoid sera an intermediate-size complex (11S), which dissociated into a $7 \mathrm{~S}$ component at an acid $\mathrm{pH}$.

That immune complexes possessing biological activity might be present in RA has been shown by Baumal and Broder (7), who isolated high molecular weight material by G-200 Sephadex chromatography from rheumatoid sera that was capable of initiating a complementdependent reaction resulting in release of histamine from guinea pig lung. This material, rheumatoid biologically active factor (RBAF), was found in both sera and synovial fluids. Subsequently, the presence of RBAF was found to correlate with disease activity (26) and to disappear as a result of successful treatment $(27,28)$.

A simpler technique for demonstration of immune complexes was introduced in 1967 by Hannestad (3). He found that certain high-titer RFs, capable of precipitating agg IgG, produced precipitin reactions with certain rheumatoid synovial fluids. Winchester, Kunkel, and Agnello (5) reported that mRFs were superior reagents for demonstrating such material. These workers isolated the reactive material and showed that it contained IgG, some of which represented IgG RF.

All of these techniques have certain drawbacks that limit their usefulness in studying the relationship of immune complex-like material to disease. Analytical ultracentrifugation is relatively insensitive and too cumbersome for analysis of large numbers of samples. The bioassay technique of Baumal and Broder is very complex and undoubtedly will prove difficult to standardize. Immunodiffusion is nonquantitative and in our experience weak bands are difficult to interpret with confidence.

The solid phase radioimmunoassay developed by us has numerous advantages over other techniques, in that it is quantitative, easily performed, sensitive, reproducible, and readily usable for analysis of many samples. The advantage of the radioimmunoassay over the quantitative precipitin test (4) lies in the small amounts of test sample and of $\mathrm{mRF}$ needed for each test and the ease and rapidity of the method, which does not require setting up the numerous points required for complete precipitin curves. The disadvantages are that it is necessary to perform a preliminary analysis on each sample for 7S IgG by radial immunodiffusion and that the assay requires a particular $\mathrm{mRF}$. Such reagents are not readily available. Furthermore, future experience may show some differences in the specificity of these RFs for IgG complexes. In preliminary experiments we have not found our RF to be specific for any IgG subclass. The $\left[{ }^{150} \mathrm{I}\right]$ agg IgG used in the assay contains material of a range of sizes (approximately 20-30S) chosen to approximate that of most of the material found in the sera tested (see Fig. 5a). We have not investigated the effect the use of such a standard might have on the quantitative aspects of measurement of immune complexes of larger or smaller size. Larger complexes may be overestimated and smaller complexes underestimated in the assay as performed. Cowdery, Treadwell, and Fritz (29) have recently described a radioimmunoassay for immune complexes in which rheumatoid serum containing polyclonal $\mathrm{RF}$ is used as the primary reagent, and the RF-immune complex aggregate is precipitated by rabbit anti-human IgM. Probably because of the low affinity of the polyclonal RF used, these authors could 
not employ it to detect immune complexes in sera containing RF.

The most important question raised by the present work is whether the material we have measured is truly an immune complex, and if so, what is the antigen. At present we cannot answer either of these questions with confidence. The experiments with the hemocyanin-antihemocyanin system demonstrated that the technique is capable of quantitating immune complexes in human serum. The density gradient ultracentrifugation studies showed that the material being measured is considerably heavier than $7 \mathrm{~S}$ IgG. Furthermore, in one rheumatoid serum known to contain $22 \mathrm{~S}$ and $11 \mathrm{~S}$ complexes, the assay detected reactive material in both regions (Fig. $5 a$ ). The nature of the antigen present in immune complexes in RA sera remains a crucial question, of course. The work of Winchester et al. (5) supports the belief that a complex composed of IgG and IgG and IgM RF certainly represents some of the reactive material. Whether we are also detecting additional antigen-antibody systems that may be relevant to the pathogenesis of RA is still unknown. The lack of close correlation between RF titer and the amount of immune complexlike material present in rheumatoid sera favors the presence of such other systems, as do other observations in our laboratory showing a lack of relationship between $\mathrm{RF}$ content and complement-fixing activity of rheumatoid sera (30).

The frequency of positive reactions in the sera of our rheumatoid patients $(26 \%)$ was somewhat less than in the group of patients reported by Winchester et al. (50\%) (5). Without more data on the populations of patients studied, our lower percentage of abnormal results cannot be explained. The correlation between the presence of immune complex-like material in sera and indices of disease severity as well as low serum complement suggests that it may be related in some way to the disease process. It does not appear to be identical with the RBAF described by Baumal and Broder (7). Measurements performed on 20 sera and 20 synovial fluids, on which assays for RBAF had been performed in their laboratory, did not show a close relationship between the presence of RBAF and agg IgG equivalent.

The low levels of immune complex-like material in the sera of patients with SLE, only 2 of 29 (7\%), were at first somewhat surprising, in view of the evidence that SLE is an immune complex disease. However, Winchester et al. (5) found that only $8 \%$ of sera from patients with hypocomplementemic SLE showed such precipitin reactions. Clq, which detects complexes in SLE sera but not in RA sera (31), and RFs appear to measure different types of immune complexes. Size of the complexes present may be an important determinant in reactivity with these two reagents. Winchester et al.
(5) have suggested that $\mathrm{mRF}$ is able to precipitate with somewhat smaller complexes than Clq. However, certain SLE sera contain 7S material capable of precipitating with Clq (31).

Recently two other methods of measuring immune complexes have been described. Nydegger, Lambert, Gerber, and Miescher (32) have developed a radioimmunoassay for immune complexes in which $\left[{ }^{125} \mathrm{I}\right] \mathrm{Clq}$ is used as reagent. These workers were able to detect reacting material in sera from two-thirds of the rheumatoid patients tested (33). Theofilopoulos, Wilson, Bokisch, and Dixon (34) described the use of complement receptors on $B$ lymphocytes for the assay of immune complexes in sera of both rabbits with experimental serum sickness and humans with glomerulonephritis. It will undoubtedly be necessary to utilize several methods of detecting such polydisperse material as immune complexes before it can be determined what each one is capable of measuring.

\section{ACKNOWLEDGMENTS}

We thank Hilton W. Brumfield for able technical assistance and Dr. I. Broder for performing analyses for RBAF on sera and synovial fluids. Dr. Peter O'Brien provided help with the statistical analysis.

Extramural financial support was provided by the $\mathrm{Na}-$ tional Institute of Arthritis and Metabolic and Digestive Diseases (AM17174) and the Minnesota Chapter of the Arthritis Foundation.

\section{REFERENCES}

1. Franklin, E. C., H. R. Holman, H. J. Müller-Eberhard, and H. G. Kunkel. 1957. An unusual protein component of high molecular weight in the serum of certain patients with rheumatoid arthritis. J. Exp. Med. 105: 425-438.

2. Hunder, G. G., and F. C. McDuffie. 1973. Hypocomplementemia in rheumatoid arthritis. Am. J. Med. 54: 461-472.

3. Hannestad, K. 1967. Presence of aggregated $\gamma$ G-globulin in certain rheumatoid synovial effusions. Clin. Exp. Immunol. 2: 511-529.

4. Winchester, R. J., V. Agnello, and H. G. Kunkel. 1970. Gamma globulin complexes in synovial fluids of patients with rheumatoid arthritis: partial characterization and relationship to lowered complement levels. Clin. Exp. Immunol. 6: 689-706.

5. Winchester, R. J., H. G. Kunkel, and V. Agnello. 1971. Occurrence of $\gamma$-globulin complexes in serum and joint fluid of rheumatoid arthritis patients : use of monoclonal rheumatoid factors as reagents for their demonstration. J. Exp. Med. 134: 286s-295s.

6. Kunkel, H. G., H. J. Müller-Eberhard, H. H. Fudenberg, and T. B. Tomasi. 1961. Gammaglobulin complexes in rheumatoid arthritis and certain other conditions. J. Clin. Invest. 40: 117-129.

7. Baumal, R., and I. Broder. 1968. Studies into the occurrence of soluble antigen-antibody complexes in disease. III. Rheumatoid arthritis and other diseases. Clin. Exp. Immunol. 3: 555-569.

8. Wide, L., and J. Porath. 1966. Radioimmunoassay of proteins with the use of Sephadex-coupled antibodies. Biochim. Biophys. Acta. 130: 257-259. 
9. Axen, R., J. Porath, and S. Ernback. 1967. Chemical coupling of peptides and proteins to polysaccharides by means of cyanogen halides. Nature (Lond.). 214: 13021304.

10. Christian, C. L. 1958. Characterization of the "reactant" (gammaglobulin factor) in the F II precipitin reaction and the F II tanned sheep cell agglutination test. J. Exp. Med. 108 : 139-157.

11. Hunter, W. M., and F. C. Greenwood. 1962. Preparation of $I^{121}$ labelled human growth hormone of high specific activity. Nature (Lond.). 194 : 495-496.

12. Mancini, G., A. O. Carbonara, and J. F. Heremans. 1965. Immunochemical quantitation of antigens by single radial immunodiffusion. Immunochemistry. 2: 235-254.

13. Steinbrocker, O., C. H. Traeger, and R. C. Batterman. 1949. Therapeutic criteria in rheumatoid arthritis. J. Am. Med. Assoc. 140: 659-662.

14. Ropes, M. W., G. A. Bennett, S. Cobb, R. Jacox, and R. A. Jessar. 1958. Revision of diagnostic criteria for rheumatoid arthritis. Bull. Rheum. Dis. 9: 175-176.

15. Hannestad, K. 1968. Rheumatoid factors reacting with autologous native $\gamma \mathrm{G}$-globulin and joint fluid $\gamma \mathrm{G}$ aggregates. Clin. Exp. Immunol. 3: 671-690.

16. Normansell, D. E., and D. R. Stanworth. 1966. Ultracentrifugal studies of the reactions of rheumatoid factor with native human $\gamma \mathrm{G}$-globulin. Immunology. 10: 527533.

17. Auernheimer, A. H., and F. O. Atchley. 1962. Modifications of micro agar precipitin test. Am. J. Clin. Pathol. 38: 548-553.

18. Fish, A. J., A. F. Michael, H. Gewurz, and R. A. Good. 1966. Immunopathologic changes in rheumatoid arthritis synovium. Arthritis Rheum. 9:267-280.

19. Rodman, W. S., R. C. Williams, Jr., P. J. Bilka, and H. J. Müller-Eberhard. 1967. Immunofluorescent localization of the third and fourth component of complement in synovial tissue from patients with rheumatoid arthritis. J. Lab. Clin. Med. 69:141-150.

20. Conn, D. L., F. C. McDuffie, and P. J. Dyck. 1972. Immunopathologic study of sural nerves in rheumatoid arthritis. Arthritis Rheum. 15: 135-143.

21. Pekin, T. J., Jr., and N. J. Zvaifler. 1962. Measurement of hemolytic complement in synovial fluids. Arthritis Rheum. 5: 314. (Abstr.)

22. Pekin, T. J., Jr., and N. J. Zvaifler. 1964. Hemolytic complement in synovial fluid. J. Clin. Invest. 43: 13721382.

23. Hedberg, H. 1963. Studies on the depressed hemolytic complement activity of synovial fluid in adult rheumatoid arthritis. Acta Rheumatol. Scand. 9: 165-193.

24. Franco, A. E., and P. H. Schur. 1971. Hypocomple- mentemia in rheumatoid arthritis. Arthritis Rheum. 14: 231-238.

25. Chodirker, W. B., and T. B. Tomasi, Jr. 1963. Lowmolecular-weight rheumatoid factor. J. Clin. Invest. 42 : 876-884.

26. Gordon, D. A., D. A. Bell, R. Baumal, and I. Broder. 1969. Studies into the occurrence of soluble antigenantibody complexes in disease. IV. Correlation between the rheumatoid biologically active factor and clinical features of rheumatoid arthritis. Clin. Exp. Immunol. $5: 57-66$.

27. Urowitz, M. B., D. A. Gordon, and I. Broder. 1973. Studies into the occurrence of soluble antigen-antibody complexes in disease. V. Second assessment of correlation between the rheumatoid biologically active factor (RBAF) and the clinical features of rheumatoid arthritis, Arthritis Rheum. 16: 225-230.

28. Russell, M. Lynn, D. A. Gordon, and I. Broder. 1974. Studies into the occurrence of soluble antigen-antibody complexes in disease. VII. Clinical laboratory correlations of immunoglobulin complexes in rheumatoid synovial fluid. J. Rheum. 1: 153-158.

29. Cowdery, J. S., Jr., P. E. Treadwell, and R. B. Fritz. 1975. A radioimmunoassay for human antigen-antibody complexes in clinical material. J. Immunol. 114: 5-9.

30. McDuffie, F. C., G. G. Hunder, and R. J. Clark. 1974 Complement fixing material in sera of patients with rheumatoid arthritis, non-identity with rheumatoid factors. Clin. Res. 22: 643a. (Abstr.)

31. Agnello, V., D. Koffler, J. W. Eisenberg, R. J. Winchester, and H. G. Kunkel. 1971. Clq precipitin in the sera of patients with systemic lupus erythematosus and other hypocomplementemic states; characterization of high and low molecular weight types. J. Exp. Med. 134: 228s-241s.

32. Nydegger, U. E., P. H. Lambert, H. Gerber, and P. A. Miescher. 1974. Circulating immune complexes in the serum in systemic lupus erythematosus and in carriers of hepatitis B antigens. Quantitation by binding to radiolabeled C1q. J. Clin. Invest. 54: 297-309.

33. Lambert, P. H., U. E. Nydegger, L. H. Perrin, J. McCormick, K. Fehr, and P. A. Miescher. 1975. Complement activation in seropositive and seronegative rheumatoid arthritis. ${ }^{125} \mathrm{I}-\mathrm{Clq}$ binding capacity and complement breakdown-products in serum and synovial fluid. Rheumatology. In press.

34. Theofilopoulos, A. N., C. B. Wilson, V. A. Bokisch, and F. J. Dixon. 1974. Binding of soluble immune complexes to human lymphoblastoid cells. II. Use of Raji cells to detect circulating immune complexes in anima and human sera. J. Exp. Med. 140: 1230-1244. 